\title{
ALPHA-LACTALBUMIN GENE POLYMORPHISMS IN RELATION TO MILK PROTEIN CONCENTRATION IN MAGHRABI CAMEL
}

\author{
Ismail, M. Ismail \\ Animal and Poultry Breeding Department, Desert Research Center, \\ El-Matareya, Cairo, Egypt \\ E-mail: ssmm_ismail@yahoo.com
}

lpha lactalbumin is one of the major proteins of camel
milk whey and essential for the biosynthesis of lactose
at the level of mammary glands. The objective of this study is identifying genetic polymorphism of the alpha-lactalbumin gene and its relationship with milk protein concentration of Maghrabi camel. Twenty one females of Maghrabi camel belonging to Camel Researche Station, Matrouh, Agricultural Research Center, Ministry of Agriculture and Land Reclamation, Egypt were used. Milk and blood samples were collected for the analysis of milk composition, protein electrophoresis and alpha-lactalbumin gene sequencing. Bioinformatics analysis was done to accomplish the PCR based sequencing technique to investigate the different Single Nucleotide Polymorphisms (SNPs) of alpha-lactalbumin gene. Results of camel milk composition percentages of protein, fat, lactose, total solids and solids not-fat were 3.2, 3.5, 4.8, 12.6 and 9.1, respectively. The alpha-lactalbumin protein band with molecular weight of $14.6 \mathrm{kDa}$ was identified in different density concentrations. Alpha-lactalbumin gene amplified band with about $1000 \mathrm{bp}$ length was detected in all studied samples. After PCR amplification, samples were divided into three groups according to milk protein concentration as follows, high (3.4-3.8\%), medium (3.0-3.4\%) and low (2.5-3.0\%). The obtained sequences were submitted and accepted at the International Gene Bank and got the accession number KF648561.1. Several SNPs were found to be repeated in many camels in the nucleotide position and molecular weights. However, SNPs at positions 255(G-A, 0.279) and 263(C-T, 0.286) of transition types showed apparent association with high milk protein concentrations. The obtained results indicated that the identified SNPs in the alpha-lactalbumin gene affect the milk protein concentration and may be used in camel selection programs.

Keywords: alpha-lactalbumin, protein electrophoresis, genetic polymorphism, Maghrabi camel 
Camel produces more milk and for a longer lactation season period than any other dairy farm animal held under the same conditions (Kaufmann and Binder, 2002). Camel milk has greater similarity to human milk and a higher concentration of vitamin $\mathrm{C}$, potassium, and iron; lower concentrations of lactose, $\beta$-casein, $\beta$-lactoglobulin, cholesterol, and fat when compared to bovine milk (Mullaicharam, 2014 and Uversky et al., 2016).

Alpha-lactalbumin is a major milk protein gene essential for the biosynthesis of lactose at the level of mammary glands. Alpha-lactalbumin directly influences the quantity and the quality of milk (Ashwell et al., 1997). In addition, it regulates cell growth (Sternhagen and Allen, 2001).

Alpha-lactalbumin is one of the major proteins of camel milk whey. Many reports suggest that Single Nucleotide Polymorphisms (SNPs) in alpha-lactalbumin potentially alter the gene expression and may be associated with differences in milk yield and quality (Bleck and Bermal, 1993 and Ramesha et al., 2008). Variation in SNF and contributed proteins may be attributed to polymorphism in sequence of causative genes. Also, Gamez et al. (2012) found two SNPs in Dairy sheep. However, Noce et al. (2016) identified 29 SNPs in Sarda sheep, plus three previously reported SNPs mapped to the alpha-lactalbumin and beta-lactoglobulin genes. Moreover, Rahmatalla et al. (2016) in the Sudanese goat breeds found seventeen SNPs. Whereas, Huang et al. (2012) studied the two major whey protein genes (alpha-lactalbumin and beta-lactoglobulin) that show associations with milk protein in Dairy cattle. Several SNPs were found to significantly associate with milk protein traits for alpha-lactalbumin. These significant SNPs explained a large proportion of the phenotypic variation of milk protein composition and can be used for selecting animals that produce milk with desired composition or desired processing and manufacturing properties. In camels, Saedi et al. (2017) analysed alpha-lactalbumin gene promoter region with about $1020 \mathrm{bp}$ length, which probably is present in both Iranian bactrians and dromedaries camel species. Five haplotypes (4 mutations) in dromedaries and 4 haplotypes (3 mutations) in bactrians were detected.

The objective of the present study was to identify genetic polymorphism of the alpha-lactalbumin gene and its relationship with milk protein concentration trait in Maghrabi camel breed.

\section{MATERIALS AND METHODS}

\section{Samples Collection}

Blood and milk samples were collected from twenty-one Maghrabi camels obtained from Camel Research Station, Matrouh, Agricultural Research Center, Ministry of Agriculture and Land Reclamation, Egypt. Camels were kept under a semi intensive production system and were 
housed in open yards. Samples were transported to the laboratory and stored at $-20^{\circ} \mathrm{C}$ for further analysis. Milk composition (protein, fat, lactose, total solids and non-fat solid contents) was determined using a lactoscan milk analyzer (Model Lactoscan SL, Milkotronic Ltd, Bulgaria).

\section{SDS-PAGE Analysis}

SDS-PAGE was carried out in a vertical gel electrophoresis apparatus (plate size: $160 \mathrm{~mm} \times 160 \mathrm{~mm}$ ) (ATTO Corp., Japan) using 5\% (w/v) stacking gel and 12\% (w/v) separating gel (Kumar et al., 2013). After electrophoresis, the gels were stained with Coomassie blue R-250 for visualization of the proteins. Molecular weight of the protein bands was determined with reference to standards (SIGMA MARKER, M-4038). Densitometry scanning of the gels was carried out using a Gel Analysis Software, Gene Tool (Mascon Global Ltd.).

\section{PCR Amplification and Sequencing}

DNA was extracted from the blood samples of 21 Maghrabi camel females using commercially available ReliaPrep ${ }^{\mathrm{TM}}$ Blood gDNA Miniprep System kit (Promega Corporation, Madison, USA), according to manufacturer's instructions.

Alpha-lactalbumin primer pairs were designed based on the published nucleotide sequence information of this gene. The primer sequences are shown in table (1).

Table (1). Primer sequences and annealing temperature.

\begin{tabular}{lll}
\hline & \multicolumn{1}{c}{ Primer sequences } & \multicolumn{1}{c}{ Protocol } \\
\hline Alpha- & Up. & initial denaturation at \\
lactalbumin & $5^{\prime}$ - AGTTTGGGGCCAGAGAGAAT-3' & $94^{\circ} \mathrm{C}$ for 4 min \\
& Down. & followed by $10 \mathrm{cycles}$ \\
$5^{\prime}-$ TTTCCTGTTCAGAGAGCGT-3' $^{\prime}$ & $\left(4 \mathrm{~min}\right.$ at $94^{\circ} \mathrm{C}, 1 \mathrm{~min}$ \\
& & at $52^{\circ} \mathrm{C}$, and $1 \mathrm{~min}$ at \\
& $\left.72^{\circ} \mathrm{C}\right)$, then $15 \mathrm{cycles}$ \\
& $\left(4 \mathrm{~min}\right.$ at $94^{\circ} \mathrm{C}, 1 \mathrm{~min}$ \\
& at $58^{\circ} \mathrm{C}$, and 1 min at \\
& $\left.72^{\circ} \mathrm{C}\right)$. \\
\hline
\end{tabular}

PCR reactions were carried out in a total volume of $25 \mu$ l containing $3 \mu 1$ of genomic DNA, $12.5 \mu 1$ of GO Taq Green Master Mix, $1 \mu 1$ of forward primer, $1 \mu \mathrm{l}$ of reverse primer and $7.5 \mu \mathrm{l}$ of nuclease-free water. The amplified DNA fragments were separated on 1.5\% agarose gel (Bioshop Canada, Burlington, Ontario, Canada), stained with ethidium bromide (Bioshop Canada), visualized on a UV Trans illuminator, photographed by Gel Doc. BIORAD 2000 and analysed with software data analysis for BioRad Model 620 USA. The specific band was cut from the gel and purified by 
gel purification kit (Jena Bioscience) according to the manufacturer's instructions. Sequencing was carried out by Ready Reaction Kit (ABI Applied Biosystems, Foster City, California, USA) on a 3130XL Genetic Analyzer (Applied Biosystems). The obtained sequences were analysed using Basic Local Aligned Tool (BLAST) online on the National Center for Biotechnology Information (NCBI) to determine the Single Nucleotide Polymorphism (SNP). Multi sequence alignments were analyzed using BIO EDIT V3 program. Pearson correlation between milk protein concentration and SNPs were calculated and tested for significantly according to SPSS (2012).

\section{RESULTS AND DISCUSSION}

\section{Milk Composition}

Camel milk composition showed averages of 3.2, 3.5, 4.8, 12.6 and $9.1 \%$ for protein, fat, lactose, total solids and solids not-fat (SNF), respectively. But, protein $\%$ was ranged from 2.5 to $3.8 \%$ among individual camels. These results are in agreement with Ibrahim (2016), who found that concentration values of protein, fat, lactose and total solids in Maghrabi camel's milk were $3.25,3.2,4.5$ and $12.15 \%$, respectively. According to most authors, the composition of camel milk varies accordance to differences of geographical origin and year of publication of the published data, beside other factors such as the physiological stage, feeding conditions, seasonal or physiological variations, genetic or health status of camel, which have also a paramount importance (Konuspayeva et al., 2009).

\section{Milk Protein Electrophoresis}

The protein fractions of camel were analyzed by SDS-PAGE (Fig. 1, 2) and identified on the basis of their molecular weight in comparison with the marker protein ladder. Most of the milk samples presented a common band of $14.6 \mathrm{kDa}$ molecular weight but with different intensities. This band corresponds to alpha-lactalbumin, which is more intense in camel milk with $72 \%$ of homogeneity. This observed band with different density concentrations might due to individual variation in milk protein concentration. This result is in full agreement with that obtained by Obaid Ullah et al. (1985), who showed that camel alpha-lactalbumin has 123 residues and a molecular mass of $14.6 \mathrm{kDa}$. Also, Kappeler (1998) reported that camel alpha-lactalbumin consists of a 123 amino acid with a molecular weight of $14.42 \mathrm{KDa}$. This slight difference in camel alpha-lactalbumin molecular weight may be due to genetic differences between camel breeds. 


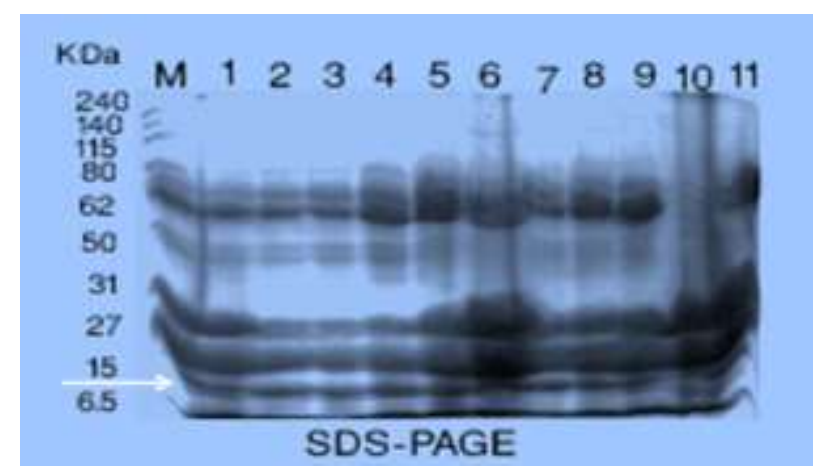

Fig. (1). Milk protein electrophoresis of Maghrabi camel (1-11).

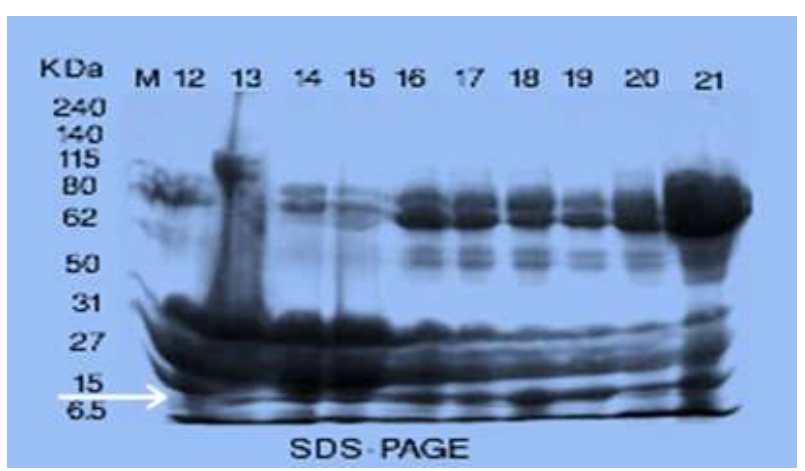

Fig. (2). Milk protein electrophoresis of Maghrabi camel (12-21).

\section{Molecular Genetic Analysis}

In the present study, bioinformatics tools were utilized to synthesize specific PCR primers for amplifying alpha-lactalbumin gene. The specificity of synthesized primers was examined in silico. Alpha-lactalbumin gene amplified band with about $1000 \mathrm{bp}$ length was detected in almost all studied samples of Maghrabi camel (Fig. 3 and 4). This band size was similar to that reported by Saedi et al. (2017) when they studied of the same region in Iranian bactrians and dromedaries camel species. The samples were divided into three groups according to milk protein concentration as high (3.4-3.8\%), medium (3.0-3.4\%) and low (2.5-3.0\%). 


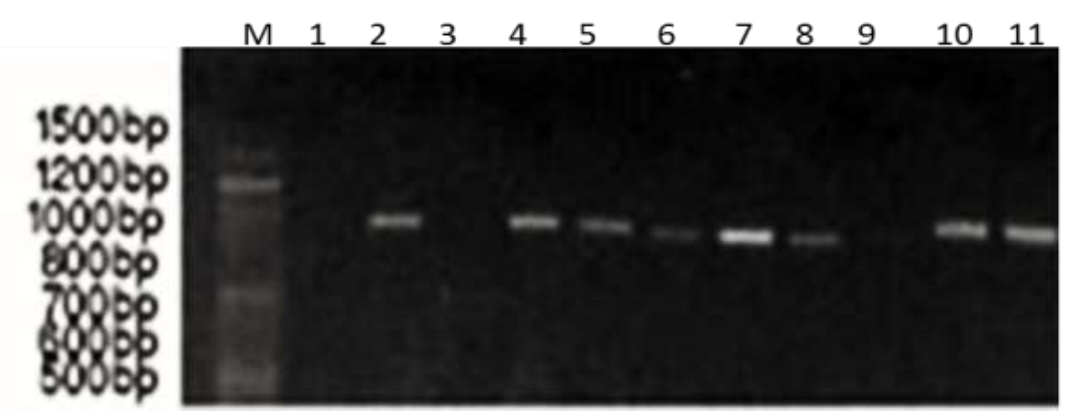

Fig. (3). Electrophoresis pattern of amplified Maghrabi camel genomic DNA with alpha-lactalbumin specific primer separated in $2 \%$ agarose gel. Molecular size marker (50 bp DNA Step Ladder). Lanes 1-11: fragments amplified.

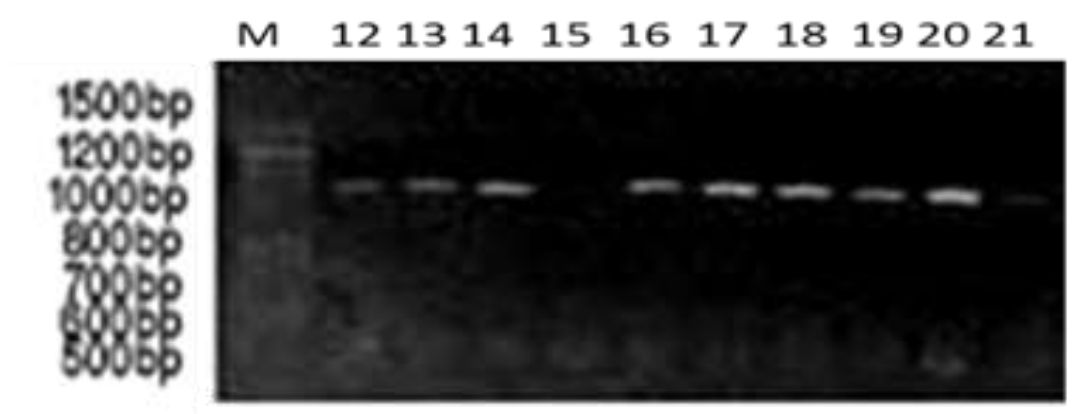

Fig. (4). Electrophoresis pattern of amplified Maghrabi camel genomic DNA with alpha-lactalbumin specific primer separated in $2 \%$ agarose gel. Molecular size marker (50 bp DNA Step Ladder). Lanes 12-21: fragments amplified.

The amplified PCR band was purified and sequenced, then the obtained sequence was alignment for the alpha-lactalbumin gene in Maghrabi camels with the available sequence at the Gene Bank, and the observed nucleotide change are shown in fig. (5) and table (2). The number of recorded SNPs ranged from 14-35 with sequence identity ranging from 77-90\%. The obtained sequences were submitted and accepted at the International Gene Bank and got the accession number of KF648561.1.

Eleven SNPs were found to be repeated in many camels in the nucleotide position and molecular weights of 115, 116, 117, 125, 129, 152, $204,220,252,255$ and 263. But the SNPs at positions $255(\mathrm{G}-\mathrm{A}, 0.279)$ and 263(C-T, 0.286) transition types are highly significantly $(p<0.01)$, linked with high milk protein concentration with correlation coefficient of 0.435 . The presence of these SNPs explains the differences between the Maghrabi camels in protein concentration. 
Similar results were obtained by Saedi et al. (2017), who found alpha-lactalbumin gene promoter region with about $1020 \mathrm{bp}$ length in both Iranian bactrians and dromedaries camel species. They reported five haplotypes (4 mutations) in dromedaries and 4 haplotypes (3 mutations) in bactrians. Also, several previous studies identified SNPs in alphalactalbumin for many species (Bleck and Bremel, 1993), two allele's polymorphism among alpha-lactalbumin in Holstein cattle were also identified. Cows with allele $\mathrm{A}$ of the gene have higher milk yield, protein yield, and fat yield; the B allele is associated with a higher percentage of protein and fat. Ramesha (2006) screened six indigenous Cattle breeds of Southern India for SNPs in the coding sequence of the bovine alphalactalbumin gene. SNPs at four positions $(772,775,792$ and 857) in exon 1 and three positions at 1231, 1264 and 1335 in exon 2 were observed. They further interpreted the effect of these SNPs in the mature protein based on the structure of bovine alpha-lactalbumin. In addition, Huang et al. (2012) studied the 2 major whey protein genes (alpha-lactalbumin and betalactoglobulin) in dairy cattle. They found several SNPs, which were significantly associated with milk protein traits. These significant SNPs explained a large proportion of the phenotypic variation of milk protein composition and can be used for selecting animals that produce milk with desired composition or desired processing and manufacturing properties. However, Gamez et al. (2012) found two alpha-lactalbumin SNPs in Dairy sheep. Noce et al. (2016) also identified 29 SNPs in Sarda sheep, in addition to three previously reported SNPs mapping for the alpha-lactalbumin and beta-lactoglobulin genes. While, Rahmatalla et al. (2016) found seventeen alpha-lactalbumin SNPs in the Sudanese goat breeds.

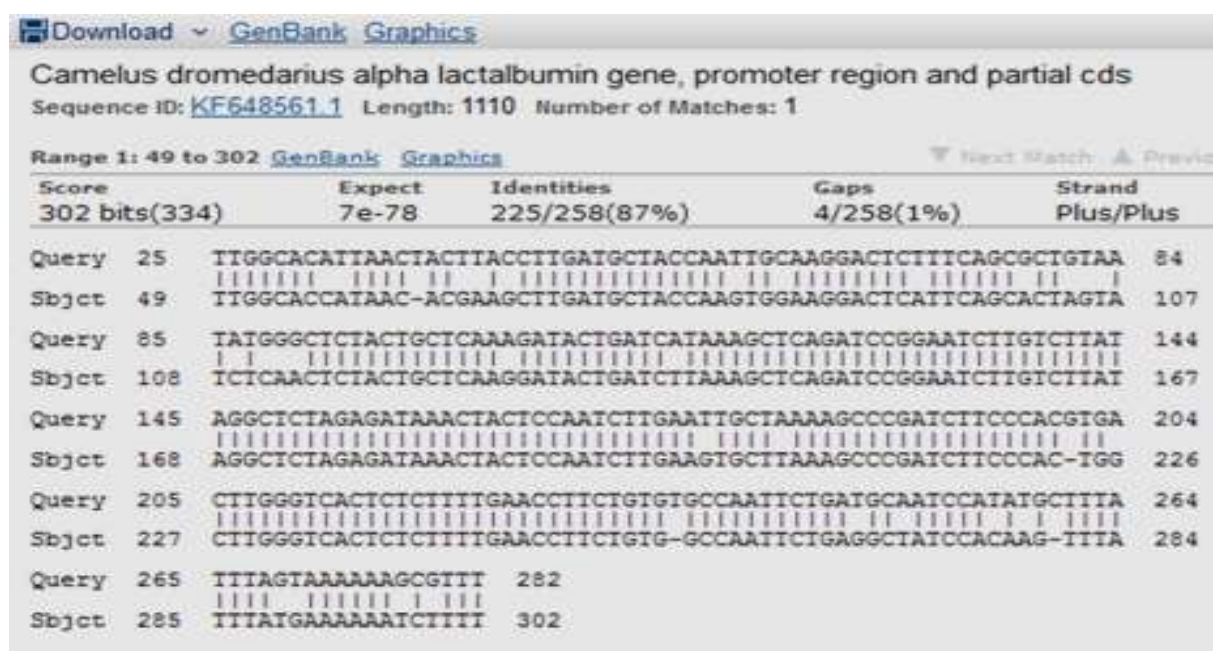

Fig. (5). Sequence alignment for the alpha-lactalbumin gene in Maghrabi camels with available sequence at the Gene Bank of KF648561.1. 
Table (2). Summary of the observed nucleotide change for alphalactalbumin gene in promoter region of Maghrabi camels.

\begin{tabular}{|c|c|c|c|c|}
\hline Animal & $\begin{array}{l}\text { No. of } \\
\text { change }\end{array}$ & $\begin{array}{c}\text { Identity } \\
\%\end{array}$ & Nucleotide change position & $\begin{array}{c}\text { Protein } \\
\%\end{array}$ \\
\hline 1 & 19 & 90 & $\begin{array}{c}33,42,43,45,55,60,63,68 \\
116,117,124,125,129,130 \\
139,153,155,162 \text { and } 167\end{array}$ & 2.5 \\
\hline 2 & 14 & 90 & $\begin{array}{r}72,78,81,82,83,86,88,89 \\
90,104,115,176,182 \text { and } 204\end{array}$ & 2.6 \\
\hline 3 & 18 & 90 & $\begin{array}{c}115,116,117,124,125,129 \\
130,139,153,155,162,167 \\
168,170,173,175,179,185 \\
\text { and } 203\end{array}$ & 2.8 \\
\hline 4 & 24 & 87 & $\begin{array}{c}33,63,72,78,81,82,83,86 \\
88,89,90,104,115,176,182, \\
204,220,245,248,252,270 \\
277 \text { and } 279\end{array}$ & 3.0 \\
\hline 5 & 20 & 87 & $\begin{array}{c}78,81,82,83,86,89,90,104, \\
115,176,182,204,220,245, \\
248,252,270,277 \text { and } 279\end{array}$ & 3.2 \\
\hline 6 & 35 & 77 & $\begin{array}{c}104,112,115,116,117,124, \\
125,129,130,139,153,155, \\
162,167,168,170,173,175, \\
179,185,186,200,203,204, \\
208,210,211,218,220,242, \\
244,246,252,255 \text { and } 263\end{array}$ & 3.4 \\
\hline 7 & 29 & 77 & $\begin{array}{c}115,125,129,130,139,153, \\
155,162,168,170,173,175, \\
179,185,186,200,203,204, \\
208,210,211,218,220,242, \\
244,246,252,255 \text { and } 263\end{array}$ & 3.6 \\
\hline 8 & 31 & 77 & $\begin{array}{l}109,112,115,116,117,124, \\
125,129,130,139,153,155, \\
162,167,168,170,173,175, \\
179,185,186,200,203,204, \\
220,242,244,246,252,255 \\
\text { and } 263\end{array}$ & 3.8 \\
\hline
\end{tabular}

The obtained results indicated that the identified SNPs in the alphalactalbumin gene promoter region may have an effect on the milk protein and lactose concentrations. The current findings could be used for selecting camels that produce much more milk with higher protein concentrations and more lactose. 


\section{CONCLUSION}

To the best of our knowledge, this is a pioneer study involving association between alpha-lactalbumin gene and milk protein concentration in Maghrabi camel breed. The SNPs explained a phenotypic variation of milk protein concentration, which may be used for selecting camels that produce more total milk yield with higher protein concentrations, as well as more lactose synthesis. Further functional analysis and genetic association studies using larger samples are probably needed to ensure the exact role of this gene in the camel breeds.

\section{REFERENCES}

Ashwell, M.S., Jr.C.E. Rexroad, R.H. Miller, P.M. Van Raden, Y. Da (1997). Detection of loci affecting milk production and health traits in an elite USHolstein population using microsatellite markers, Animal Genetics, 28: 216-222.

Bleck, T. and D. Bremel (1993). Correlation of the alpha lactalbumin $(+15)$ polymorphism to milk production and milk composition of Holsteins. J. Dairy Sci., 76: 2292-2298.

Gamez, E., B. Gutierrez-Gil, G. Sahana, J.B. Sanchez Bayon and J.J. Arranz (2012). GWA analysis for milk production traits in dairy sheep and genetic support for a QTN influencing milk protein percentage in the LALBA gene. PLoS One, 7 (10): e47782. doi:10.1371/journal.pone.0047782

Huang, W., F. Peñagaricano, K.R. Ahmad, J.A. Lucey, K.A. Weigel and H. Khatib (2012). Association between milk protein gene variants and protein composition traits in dairy cattle. J. Dairy Sci., 95 (1): 440449.

Ibrahim, A.H. (2016). Determination of lactulose and furosine contents during heat treatment of camel milk: as a new method for discriminating the degree of heat treatment given to camel milk. Zagazig J. Agric. Res., 43 (5):1973-1984.

Kappeler, S.R. (1998). Compositional and structural analysis of camel milk proteins with emphasis on protective proteins. Ph.D. Thesis, Swiss Federal Institute of Technology, Zurich, Switzerland.

Kaufmann, B. and C. Binder (2002). In "Production, Aims and Functions of camels in Keny: A pastoral System". Hulsebusch, C.G. and B.A. Kaufmann (Eds.), p.15-28.

Konuspayeva, G., B. Faye and G. Loiseau (2009). The composition of camel milk: a meta-analysis of the literature data. Journal of Food Composition and Analysis, 22 (2): 95-101. 
Kumar, A., P.K. Rout and B.P. Mohanty (2013). Identification of milk protein polymorphism in Indian goats by $2 \mathrm{D}$ gel electrophoresis. J. Proteomics Bioinform., 6: 001-004.

Mullaicharam, A.R. (2014). A review on medicinal properties of camel milk. World J. Pharm. Sci., 2: 237-242.

Noce, A., M. Pazzola, M.L. Dettori, M. Amills, A. Castello, A. Cecchinato, G. Bittante and G.M. Vacca (2016). Variations at regulatory regions of the milk protein genes are associated with milk traits and coagulation properties in the Sarda sheep. Animal Genetics, 47 (6): 717-726.

Obaid Ullah, B.E.G., H. Bahr-Lindstorm, Z.H. Zaidi and H. Jorvall (1985). The primary structure of a-lactalbumin from camel milk. Eur. J. Biochern., 147: 233-239.

Rahmatalla, S.A., A. Said Ahmed, M. Reißmann, G.A. Brockmann (2016). Genetic variation of the alpha-lactalbumin gene in Sudanese goat breeds. Available online: www.tropentag.de/2016/abstracts/posters/969.pdf

Ramesha, K.P. (2006). Single nucleotide polymorphisms $a$-lactalbumin gene in cattle and their effect in mature protein. The Indian Journal of Animal Sciences, 76 (10): 816-820.

Ramesha, K.P., H. Khosravinia, G. Shivraj and M.R.S. Rao (2008). Alphalactalbumin gene polymorphism: A preliminary study on two breeds of the river buffalo (Bubalus bubalis). J. Mol. Biol. Biotech., 16: 47-52.

Saedi, N., M. Tahmoorespur, M.R. Nassiri, M.H. Sekhavati and M. Raei toroqi (2017). Sequencing and analysis of partial promoter region of alpha lactalbumin gene in iranian dromedary and bactrian camels. Modern Genetics Journal, 11 (4).

SPSS (2012). In "Statistical Package for Social Science". Release 11.5, SPSS INC, Chicago. USA.

Sternhagen, L.G. and J.C. Allen (2001). Growth rates of a human colon adenocarcinoma cell line are regulated by the milk protein $\alpha$ lactalbumin. Adv. Exp. Med. Biol., 501: 115-120.

Uversky, V.N., S.E. Permyakov, L. Breydo, E.M. Redwan, H.A. Almehdar and E.A. Permyakov (2016). Disorder in milk proteins: $\alpha$ lactalbumin. Part B. A multifunctional whey protein acting as an oli-gomeric molten globular "oil container" in the anti-tumorigenic drugs, liprotides. Current Protein and Peptide Science, 17 (6). 


\section{تعدد الأشكال المظهرية لجين الفالاكتالبومين وعلاقتها بتركيز بروتين اللبن في الإبل المغربي}

إسماعيل عحم إسماعيل

قسم تربية الحيوان و الدواجن، مركز بحوث الصحر اءع، المطرية، القاهرة، مصر

ألفالاكتالبومين هو أحد البروتينات الرئيسية في شرش ألبان الإبل وهو أساسي للتخليق الأني

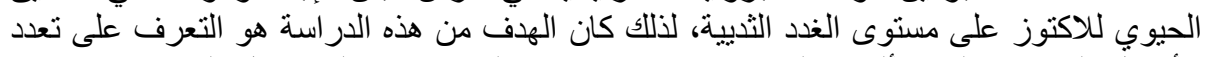

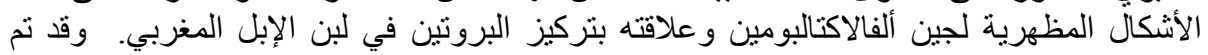

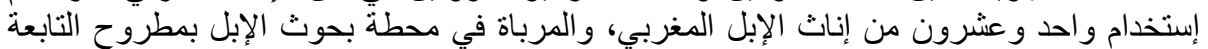

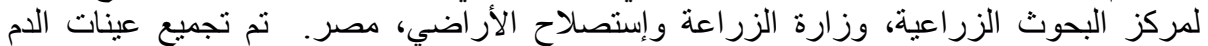

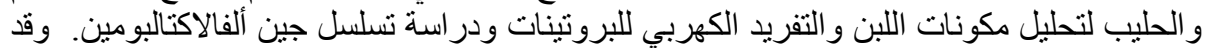
تم إستخدام Bioinformatics analysis لدراسة SNPs المختلفة في تسلسل جين الأبن لاكتالبومين. وقد أظهرت النتائج أن النسب المئوية لمكونات لبن الإبل من البن البروتين و الدهونة

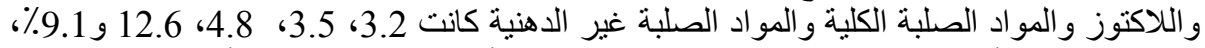

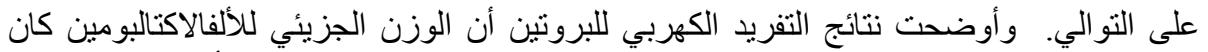

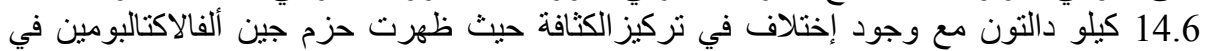

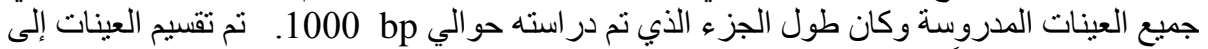

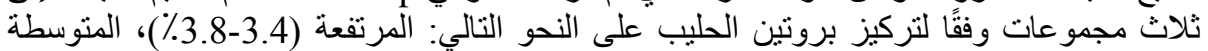

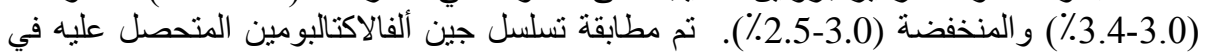
بنك الجينات الدولي ـKF648561.1.

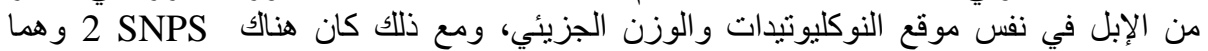

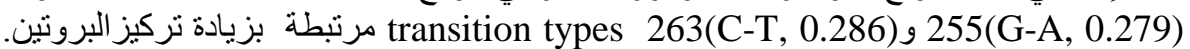
وقد خلصت الدراسة إلى أن SNPs في جين الفالاكتالبومين التي تم تحديدها كان لها تأثير على تركيز بروتين اللبن ويمكن إستخدامها في بر امج إنتخاب وتحسين إنتاجية الإبل. 